\title{
EDITORIAL
}

\section{Perspective: the late preterm infant}

\author{
Journal of Perinatology (2013) 33, S1; doi:10.1038/jp.2013.50
}

It is rare that neonatal educational conferences today do not have a presentation dealing with The Late Preterm Infant. Think about the confusion over the years as we deleted the words, Near Term, Marginally Preterm, Moderately Preterm, Minimally Preterm and Mildly Preterm. The replacement of Near Term with Late Preterm was most important, as Near Term implied maturity and a similar risk for morbidity and mortality as the Term Infant. We now realize that Late Preterm implies immaturity and there is a higher risk for morbidity and mortality. As Late Preterm Infants are often the size and weight of Term Infants problems exist as caregivers and parents treat this class of babies as if they are developmentally mature.

As is discussed throughout this supplement, there are many clinical conditions that are typical of The Late Preterm Infant. These specific problems have both an embryologic and physiologic basis. In addition, there is also an economic health-care burden as the difference in the cost of care for a Late Preterm Infant compared with a Term Infant is significant.

In 2006, the Committee on the Fetus and Newborn in a clinical report ${ }^{1}$ defined The Late Preterm Infant as a population at risk. In fact, these babies were described as early as 1540 as Thomas Raynalde published the following 'Of the time of birth and which is called natural or unnatural: The due season is most commonly after the ninth month or about 40 weeks after the conception, although some be delivered sometimes, in the seventh month and the child proves very well. But such as are born in the eight month, either they be dead before the birth, or else live not long after'.
This supplement to the Journal of Perinatology will be invaluable to all health-care providers dealing with The Late Preterm Infant.

\section{CONFLICT OF INTEREST}

The authors declare no conflict of interest.

\section{ACKNOWLEDGEMENTS}

This work is published as part of a supplement facilitated by The National Perinatal Association, and sponsored by Philips Mother \& Child Care and GE Healthcare Maternal-Infant Care. These organizations had no input or editing rights to the content included.

GI Martin

Director Emeritus Journal of Perinatology, Director Emeritus Neonatal Intensive Care Unit, Citrus Valley Medical Center - Queen of the Valley Campus, Pediatrix Medical Group, West Covina, CA, USA E-mail: gimartinmd@yahoo.com

\section{REFERENCES}

1 Engle WA, Tomashek KM, Wallman C. Late Preterm Infants: A Population at Risk. Pediatrics 2007; 120: 1390-1401.

2 Raynalde T. The Byrthe of Mankynde. Book II, Chap. I, Circa, 1540.

(c) This work is licensed under a Creative Commons AttributionSOMERIGHISRESERVED NonCommercial-NoDerivs 3.0 Unported License. To view a copy of this license, visit http://creativecommons.org/licenses/by-nc-nd/3.0/ 